\title{
The Effects of Whole Body Vibration Application on Jump and Balance Performance in University Students
}

\author{
Barış Gürol $^{1}$, Gülsün Güven ${ }^{1}$ \& Elvin Onarıcı Güngör ${ }^{1}$ \\ ${ }^{1}$ Faculty of Sports Sciences, Eskişehir Technical University, Turkey \\ Correspondence: Barış Gürol, Faculty of Sports Sciences, Eskişehir Technical University, Eskisehir, Turkey, \\ E-mail: bgurol@eskisehir.edu.tr
}

Received: September 28, 2019

Accepted: October 20, 2019 Online Published: October 26, 2019

doi:10.5539/jel.v8n6p110

URL: https://doi.org/10.5539/jel.v8n6p110

\begin{abstract}
The aim of this research was to investigate the effect of vibration applications on muscle strength and balance. As the subjects to the research, nineteen male sport science students (age: $21.45 \pm 2.16$ years, height: $177.55 \pm 7.24$ $\mathrm{cm}$, body mass: $71.62 \pm 11.02 \mathrm{~kg}$ ) voluntarily participated in the study. The students were exposed to vibration in squat exercise position before they were exposed to vibration at $25 \mathrm{~Hz}, 50 \mathrm{~Hz}$ frequency and control (no-vibration) on three different application days. Before and after the vibration exposure, jump tests and balance tests were administered right after the $5^{\text {th }}, 10^{\text {th }}$ and $15^{\text {th }}$ min in the wake of the vibration. A statistically significant difference was found in active and squat jump heights administered following the $25 \mathrm{~Hz}$ and $50 \mathrm{~Hz}$ frequency applications $(p \leq 0.05)$. No significant differences were found in the jump heights in control group ( $p>0.05)$. While there was no significant difference found in balance tests performed after $25 \mathrm{~Hz}$ and $50 \mathrm{~Hz}$ vibration applications ( $p>0.05)$, a significant difference was found after the control application ( $\mathrm{p} \leq 0.05)$. As a result, there was an increase in jump heights following the acute vibration application however, no change was seen in balance scores. Practicing acute vibration applications can be recommended to increase jump height especially before the competitions and applications.
\end{abstract}

Keywords: whole body vibration application, vertical jump, kinaesthetic balance ability

\section{Introduction}

Vibration is defined as a mechanical and sinusoidal phenomenon whereby oscillations are produced by an object moving periodically according to its stationary position (Kin Işler, 2007). As for whole body vibration, it is applied for the improvement of sportive performance by transferring the mechanical energy generated out of vibrations to the whole human body (Hagberg et al., 2006; Ricky et al., 2011).

The first instances of the use of vibration application in the field of sports took place in Russia in 1980 and so far, numerous studies have been carried out in relation to its acute and chronical effects. The biggest improvement accompanied by the acute effects was seen in untrained groups (Wilcock et al., 2009) and was generally applied in order to prevent muscular exhaustion before the application (Rhea \& Kenn, 2009). While, up until the start of mid-1990s, vibration was predominantly used to enhance muscular strength during weight applications, it was subsequently used for the improvement of balance and movement functions, the prevention of osteoporosis by increasing bone density, the regulation of muscular tonus and in many other fields (Liao et al., 2014).

When exposed to muscle or tendon, vibration produces a reflex muscle contraction. This reflex contraction is called as tonic vibration reflex (TVR) (Apple et al., 2010; Krol et al., 2011; Torvinen et al., 2002a). It was stated that the tonic contraction combined with strength training can enhance the maximal voluntary contraction in the muscle and that this enhancement is caused by the ignition of motor unit synchronization as well as the previously inactive motor units (Latash, 1998; Issurin \& Tenenbaum, 1999; Mester et al., 2005; Apple et al., 2010; Krol et al., 2011; http-1). This reflex activates the muscle spindles, thus activating the muscle fibrils with alpha motor neurons (Torvinen et al., 2002b) and later emerges as involuntary contractions increasing gradually, therefore it increases the contraction of the muscle (Cardinale \& Bosco, 2003; Kin Işler, 2007).

Vibration was defined as a "mechanical stimulus characterised by oscillatory motions". From a biomechanical perspective, vibration has three parameters. These parameters are defined as: amplitude which determines the oscillation range of vibration in terms of millimetres, frequency which indicates the number of vibration 
repetitions produced per second and force which is provided by the acceleration generated during the vibration (Cardinale \& Bosco, 2003; Mansfeld, 2004; Tok, 2007; Bogaerts et al., 2007; Mikhael et al., 2010; Cochrane, 2011). Amplitude is defined as the distance or extent of the vibrational motion; frequency is the number of repetitions of this motion within a specific time and force is the acceleration of the motion (Tok, 2007; Bogaerts et al., 2007; Mikhael et al., 2010; Cochrane, 2011). A tolerance threshold is identified in order to demonstrate the potential effects of vibration application (Jordan et al., 2005).

In vibration application, low frequency is designated as $8 \mathrm{~Hz}$ (Silva et al., 2008), medium frequency as 30-35 Hz (Rhea \& Kenn, 2009) and high frequency as $50 \mathrm{~Hz}$ (Bedient et al., 2009) or $65 \mathrm{~Hz}$ (Luo et al., 2009), whereas, Wilcock et al. (2009) accepted $30 \mathrm{~Hz}$ frequency as the optimum level for maximal strength training.

\subsection{Vibration Application}

The use of vibration as a means of performance enhancement is called as vibration stimulation (Issurin, Liebermann, \& Tennenbaum, 1994), vibration exercise or vibration application (Cardinale \& Wakeling, 2005; Jordan et al., 2005; Rehn et al., 2007; Cheng et al., 2012; Hortabagyi et al., 2015).

In addition to the studies conducted on the effects of vibration applications on strength (Cormie et al., 2006; Tillaar, 2006; Roelants et al., 2006; Annino et al., 2007; Silva et al., 2008; Rhea \& Kenn, 2009), there are also studies on the fact that strength trainings done on a regular basis leaded to a significant increase in static and dynamic balance, as well (Mattacola \& Lloyd, 1997; Hansen et al., 2000; Felicetti et al., 2004; Erkmen et al., 2007; Vrbanic et al., 2007; Filippini et al., 2008). Besides, there are also studies that do not support performance enhancement such as jumping, speed, agility, strength etc. (Cochrane \& Hawke, 2007; Ronnestad, 2009). The aim of this research was to investigate the effect of vibration applications on muscle strength and balance.

\section{Methods}

\subsection{Subjects}

Twenty-five male students of Faculty of Sport Sciences, aged between 18-24, who have not sustained any kind of injury in the past year participated in the study as voluntary subjects. Six subjects withdrew from the study at their own request, and the study was completed with 19 subjects. The descriptive statistics of the subjects are presented in Table 1. Prior to study, the subjects were informed by the researcher of the measurements and tests to be administered to the subjects, hence directing their attention to the study.

Table 1. Descriptive statistics of the subjects

\begin{tabular}{ll}
\hline $\mathrm{n}=19$ & mean $\pm \mathrm{sd}$ \\
\hline Age $($ year $)$ & $21.45 \pm 2.16$ \\
Height $(\mathrm{cm})$ & $177.55 \pm 7.24$ \\
Body mass $(\mathrm{kg})$ & $71.62 \pm 11.02$ \\
BMI $\left(\mathrm{kg} / \mathrm{m}^{2}\right)$ & $22.63 \pm 2.41$ \\
BFP $(\%)$ & $13.93 \pm 4.58$ \\
\hline
\end{tabular}

Note. BMI: Body mass index, BFP: Body fat percent.

\subsection{Research Procedure}

The vibration loading was conducted in a high vertical transposition, on three plates and mostly in vertical vibrations $(4 \mathrm{~mm})$. The students were exposed to vibration on the vibration plate (Power Plate, pro5, AIRdaptive, London, UK) in a standing position while feet open shoulder-wide and slightly leaning forward, at a $25 \mathrm{~Hz}$ frequency on the $1^{\text {st }}$ day of application, at $50 \mathrm{~Hz}$ frequency on the $2^{\text {nd }}$ day and without any vibration (control) on the $3^{\text {rd }}$ day at $110^{\circ} \mathrm{knee}$ angle in squat exercise position. In control, participants used the vibration platform in the same manner as whole body vibration, except that they received no vibration application $(0 \mathrm{~Hz}, 0 \mathrm{~mm})$. All exercises were performed in a way to provide 60-s of active vibration application. Before and after the vibration exposure, jump tests (Lamont et al., 2010; Dallas et al., 2014; Wallmann et al., 2019) and balance tests were administered right after the $5^{\text {th }}, 10^{\text {th }}$ and $15^{\text {th }}$ min in the wake of the vibration. On an introductory basis, the subjects underwent all tests and vibration applications carried out within one week before the tests and applications for trial purposes. Each subject underwent one test each day and these tests were performed at the same hours of the day for every student. Each test lasted approximately 20 -min. Active and squat jump tests were used as jump tests, the jump heights of the students were measured by means of a digital wireless jumping device fastened around their waists. Double-leg balance scores were identified using kinaesthetic balancing device (SportKAT 4000-TS, LLC, Vista, CA, USA). 
Table 2. Flowchart of experimental design

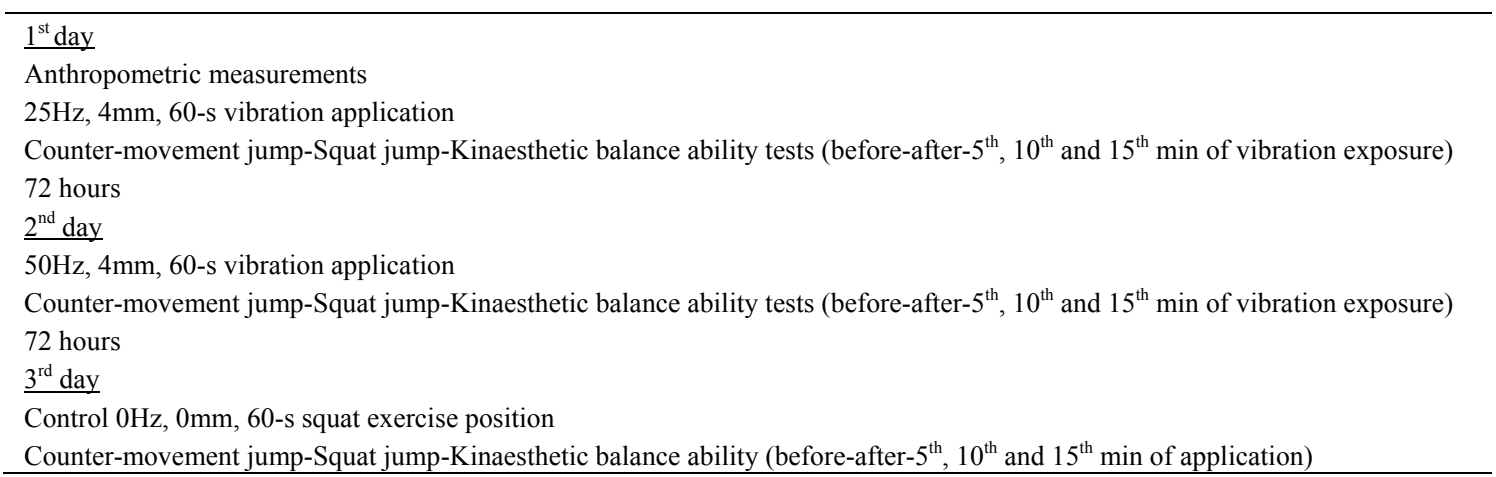

\subsection{Anthropometric Measurements}

The heights of the subjects participating in the study were measured using a stadiometer (Holtain, UK) having $\pm 0.1 \mathrm{~mm}$ sensitivity. The body mass of the subjects were measured in $\mathrm{kg}$ as they were standing in an anatomical position in bare foot with merely their shorts on using an electronic laboratory scale (Seca, Vogel, \& Halke, Hamburg) having $0.1 \mathrm{~kg}$ sensitivity. The average of both measurements performed in anthropometric measurements was taken. The body fat percentage, lean body mass, segmental fat and muscle distribution were performed through body composition analyser (Tanita MC180MA, Tanita, Japan)

\subsection{Jump Tests}

A jump measurement device system having a light mechanism and running also on a computer software, which is wireless and can also be fastened around the body with a waist belt, (Freejump, Sensorize, Rome, Italy) was used to take the measurement of jump height, jump time and hang time of the subjects during their squat and active jumps. A log of jump records of the subjects at $5^{\text {th }}-10^{\text {th }}$ and $15^{\text {th }}$ min of their jump before and after the treatments conducted by the subjects at different frequencies was kept.

\subsection{Balance Tests}

Having set the kinaesthetic balance device having a computer software and balance platform which can compare the barefoot double-leg static balance scores and perform left/right leg and anterior posterior comparison and test static and dynamic balance to $6 \mathrm{psi}$ as was stated by Schnurrer et al. (2007); the double-leg static balance of the subjects was tested and recorded as value-balance score (SportKAT 4000-TS, LLC, Vista, CA, USA). With an attempt to eliminate its effect on the balance, the subjects were made to fasten their arms in a crossed position in front of the chest. The pre-application and post-application balance scores at $5^{\text {th }}-10^{\text {th }}$ and $15^{\text {th }}$ min were recorded.

\subsection{Data Analysis}

SPSS 20 statistical program was used for statistical analysis of the data. According to the test of sphericity analysis of Skewness-Kurtosis and Mauchly, it was seen that the data were normally distributed and there were no extreme values according to the graphs. After calculating the mean and standard deviations of all data obtained from the subjects, Repeated Measures Anova test was performed to determine whether body composition, jump and balance parameters differed or not. Significance level was accepted as $\mathrm{p} \leq 0.05$.

\section{Results}

Table 3. Mean and standart deviations values of the tests

\begin{tabular}{|c|c|c|c|c|c|c|}
\hline \multirow[t]{2}{*}{ Test $(\mathrm{n}=19)$} & & pre_test & post_test & $5^{\text {th }}$ min & $10^{\text {th }} \min$ & $15^{\text {th }} \min$ \\
\hline & & \multicolumn{5}{|l|}{ mean \pm sd } \\
\hline \multirow[t]{3}{*}{ Squat jump (cm) } & $25 \mathrm{~Hz}$ & $32.95 \pm 6.46$ & $32.32 \pm 6.41$ & $33.63 \pm 6.65$ & $33.95 \pm 6.44$ & $34.26 \pm 6.75$ \\
\hline & $50 \mathrm{~Hz}$ & $34.58 \pm 4.81$ & $33.79 \pm 5.31$ & $34.95 \pm 5.05$ & $34.89 \pm 5.16$ & $35.00 \pm 5.60$ \\
\hline & Control & $34.21 \pm 5.28$ & $34.58 \pm 6.29$ & $34.53 \pm 5.14$ & $35.26 \pm 5.28$ & $35.21 \pm 5.38$ \\
\hline \multirow[t]{3}{*}{ Counter movement jump (cm) } & $25 \mathrm{~Hz}$ & $35.26 \pm 6.32$ & $34.63 \pm 5.60$ & $36.05 \pm 6.27$ & $36.42 \pm 6.64$ & $36.26 \pm 6.80$ \\
\hline & $50 \mathrm{~Hz}$ & $36.32 \pm 5.53$ & $35.00 \pm 5.59$ & $36.42 \pm 5.75$ & $36.37 \pm 5.96$ & $36.89 \pm 5.92$ \\
\hline & Control & $37.05 \pm 5.79$ & $36.84 \pm 6.41$ & $36.68 \pm 5.12$ & $37.11 \pm 5.16$ & $37.68 \pm 5.59$ \\
\hline \multirow[t]{3}{*}{ Kinesthetic balance ability (score) } & $25 \mathrm{~Hz}$ & $229 \pm 84$ & $251 \pm 104$ & $224 \pm 83$ & $224 \pm 121$ & $211 \pm 78.6$ \\
\hline & $50 \mathrm{~Hz}$ & $242 \pm 130$ & $211 \pm 96$ & $208 \pm 84$ & $213 \pm 140$ & $221 \pm 165$ \\
\hline & Control & $245 \pm 110$ & $217 \pm 83$ & $248 \pm 130$ & $185 \pm 67$ & $237 \pm 83$ \\
\hline
\end{tabular}


Table 3 shows that mean and standart deviations values of the tests for different vibration frequencies and different test times.

Table 4. Comparison of three vibration test groups according to squat jump, counter-movement jump and kinaesthetic balance ability

\begin{tabular}{|c|c|c|c|c|c|c|}
\hline Test $(n=19)$ & & $\mathrm{df}$ & Mean square & $\mathrm{F}$ & Sig. & Partial eta squared \\
\hline \multirow[t]{3}{*}{ Squat Jump (cm) } & $25 \mathrm{~Hz}$ & 4 & 11.763 & 4.232 & $.004 *$ & .190 \\
\hline & $50 \mathrm{~Hz}$ & 4 & 4.826 & 2.823 & $.031 *$ & .136 \\
\hline & Control & 4 & 4.016 & 2.253 & .072 & .111 \\
\hline \multirow[t]{3}{*}{ Counter movement jump (cm) } & $25 \mathrm{~Hz}$ & 4 & 10.879 & 4.165 & $.004 *$ & .188 \\
\hline & $50 \mathrm{~Hz}$ & 4 & 9.563 & 4.432 & $.003 *$ & .198 \\
\hline & Control & 4 & 2.753 & 1.010 & .408 & .053 \\
\hline \multirow[t]{3}{*}{ Kineasthetic balance ability (score) } & $25 \mathrm{~Hz}$ & 4 & 4000.884 & .745 & .565 & .040 \\
\hline & $50 \mathrm{~Hz}$ & 4 & 3625.721 & 1.208 & .315 & .063 \\
\hline & Control & 4 & 12682.668 & 3.035 & $.023 *$ & .144 \\
\hline
\end{tabular}

Note. $\mathrm{p} \leq 0.05$.

A statistically significant difference was found in active and squat jump heights administered following the $25 \mathrm{~Hz}$ and $50 \mathrm{~Hz}$ frequency applications $(\mathrm{p} \leq 0.05)$. No significant differences were found in the jump heights in control group $(\mathrm{p}>0.05)$. While there was no significant difference found in balance tests performed after $25 \mathrm{~Hz}$ and $50 \mathrm{~Hz}$ vibration applications ( $p>0.05)$, a significant difference was found after the control application $(p \leq 0.05)$.

Table 5. Comparison of five different measurement times regarding to squat jump, counter-movement jump and kinaesthetic balance ability

\begin{tabular}{|c|c|c|c|c|c|c|}
\hline Test $(n=19)$ & & $\mathrm{df}$ & Mean square & $\mathrm{F}$ & Sig. & Partial eta squared \\
\hline \multirow[t]{5}{*}{ Squat jump (cm) } & pre_test & 2 & 13.912 & 3.949 & $.028^{*}$ & .180 \\
\hline & post_test & 2 & 25.070 & 3.763 & $.033^{*}$ & .173 \\
\hline & $5^{\text {th }}-\min ^{-}$ & 2 & 8.579 & 2.214 & .124 & .110 \\
\hline & $10^{\mathrm{th}}{ }_{-} \min$ & 2 & 8.754 & 2.645 & .085 & .128 \\
\hline & $15^{\text {th }}-\min$ & 2 & 4.702 & 1.639 & .208 & .083 \\
\hline \multirow[t]{5}{*}{ Counter movement jump (cm) } & pre_test & 2 & 15.368 & 4.538 & $.017 *$ & .201 \\
\hline & post_test & 2 & 26.649 & 4.030 & $.026^{*}$ & .183 \\
\hline & $5^{\text {th }}-\min$ & 2 & 1.912 & .726 & .491 & .039 \\
\hline & $10^{\text {th }}$ min & 2 & 3.211 & 1.116 & .339 & .058 \\
\hline & $15^{\text {th }}-\min$ & 2 & 9.632 & 3.005 & .062 & .143 \\
\hline \multirow[t]{5}{*}{ Kinaesthetic balance ability (score) } & pre_test & 2 & 1362.233 & .144 & .866 & .008 \\
\hline & post_test & 2 & 8472.333 & 1.334 & .276 & .069 \\
\hline & $5^{\text {th }}-{ }_{-} \min$ & 2 & 7639.895 & .877 & .425 & .046 \\
\hline & $10^{\overline{\mathrm{th}}}$ min & 2 & 7588.754 & 1.522 & .232 & .078 \\
\hline & $15^{\mathrm{th}} \min$ & 2 & 3267.00 & .276 & .760 & .015 \\
\hline
\end{tabular}

Note. $\mathrm{p} \leq 0.05$.

As a result, there was an increase in jump heights following the acute vibration application however, no change was seen in balance scores.

\section{Discussion and Conclusions}

In the study Yılmaz and Kin-Işler (2013) tried to determine the effect of acute whole-body vibration exposed at different frequencies on repeated sprint performance, 15 students from Department of Sport Sciences voluntarily participated in the study. The participants randomly participated in the repetitive sprint test following the whole body application performed at $30 \mathrm{~Hz}$ and $40 \mathrm{~Hz}$ frequencies and $4 \mathrm{~mm}$ amplitude without being exposed to vibration application. While the whole body vibration application was performed in half-squat position in $60-\mathrm{s}$, the participants, subsequent to a 60 -s passive resting period, took the $12 \times 20 \mathrm{~m}$ repeated sprint test at 20 -s resting intervals. As a result of the study, the findings showed that whole body vibration acutely performed at different frequencies did not have an effect on repeated sprint performance.

Aktuğ et al. (2019) compared the measurements of the vertical jump and agility in the athletes before performing any exercise on the low extremity, with the measurements after a vibration application was applied; and stated that, 
after the application, vertical jump and agility performance improved on a statistically significant level. The results of the study show similarity to our research in terms of jump heights.

Kaçoğlu (2019) examined the effects of whole-body vibration (WBV) application on unilateral static balance. It was concluded that vibration application performed at $30 \mathrm{~Hz}$ frequency, $2 \mathrm{~mm}$ amplitude and in $2 \times 60$-s does not provide an adaptation that improves balance ability in healthy individuals.

Kurt and Pekünlü (2015) investigated the effects of whole body vibration exercise targeting forearm, leg and trunk muscles. During whole body vibration intervention, four isometric exercises $(4 \times 60-\mathrm{s}, 26 \mathrm{~Hz}, 4 \mathrm{~mm})$ were performed The result of the study stated that squat jump, trunk flexion and isometric leg strength performances were not affected by vibration application for well-trained combat athletes.

Thirty-three amateur male volunteers aged 18-25 participated in the study in which Şengur et al. (2018) investigated the effect of acute vibration application applied on lower extremity in football players on shooting velocity, shooting accuracy and agility performance. The participants were tested twice, one being without any exercise and the other being after the vibration application and it was determined that shooting velocity, accuracy and agility performance improved on a statistically significant level.

Torvinen et al. (2002a, 2002b) investigated the effects of a 4-min long vibration exercise on the balance performance of healthy individuals and stated that there was no change induced in the balance performance after 2 and 60-min.

In their research, Wang et al. (2014) investigated the effect of vibration and traditional exercise methods on the maximum contraction force of the quadriceps in 21 elite athletes. The vibration exercise performed at a frequency of $30 \mathrm{~Hz}$ and $4 \mathrm{~mm}$ amplitude for 4 weeks was combined with traditional strength trainings. An eccentric muscle strength and significant improvements in the sprint levels of the athletes were detected in the group where vibration was applied together with strength trainings compared to group performing the traditional strength applications only. Wyon et al. (2010) investigated the effect of vibration exercises on vertical jump height in 17 female dancers. There was a significant increase found in the vertical jump height of the dancers who were exposed to a vibration for $40-\mathrm{s}$ at $35-40 \mathrm{~Hz}$ frequency for 4 weeks.

In another study, it was stated that an anterior increase in balance performance tested after acute vibration application $(30 \mathrm{~Hz}, 2 \mathrm{~mm})$ involving dynamic squat for rhythmic gymnasts (Despina et al., 2014).

Acute vibration application of elite and amateur male football players (static squat $3 \times 60 \mathrm{sn}, 40 \mathrm{~Hz}, 4 \mathrm{~mm}$ ) was claimed to increase the balance and it was stated that this may be due to possible increase in flexibility (Cloak et al., 2016).

The study conducted by Cormie et al (2006) found that acute vibration application increased jump height and suggested that acute vibration application applied to the whole body would be a good warm-up method to increase vertical jump height while the optimal dose amount being unclear. Bosco et al (1998) determined that 10 days of squat exercise performed on the vibration platform increased the jumping performance.

In the literature, there are studies on the acute and chronic exercises of whole body vibration which changes the jumping performance (Bosco et al., 1998; Rittweger et al., 2001; Cormie et al., 2006).

Mattacola and Lloyd (1997) determined that proprioceptive resistance applications can improve balance ability under dynamic test conditions. Iwamoto et al. (2012) found that the balance parameters of the body including standing on one foot and standing one after another showed a statistically significant increase after whole-body vibration application performed at a frequency of $20 \mathrm{~Hz}$, for $4 \mathrm{~min} /$ day for 2 days a week for a period of 6 weeks.

The aim of this research was to investigate the effects of acute vibration application on active-squat jump and static double-leg balance. According to the results, there was an increase detected in the jump heights after the acute vibration application however, no change took place in balance scores.

In the current study, $25 \mathrm{~Hz}$ and $50 \mathrm{~Hz}$ frequencies and $4 \mathrm{~mm}$ amplitude were limitations for vibration application. In the future studies, researchers can apply different frequencies and amplitudes.

Today, vibration exercises have been used in many areas such as local or whole body vibration. However, a standardization on the effects of vibration has not been established yet in the studies. The most important reason for this is that the most appropriate criteria for vibration have not been fully established yet. If the effects of vibration can be fully understood in future randomized controlled studies, it is predicted that vibration applications will be a very important alternative to be used instead of or along with traditional exercise.

Vibration applications can also be performed with static flexibility application (Epperson, 2009), squat, deep squat, single-leg squat (Bogaerts et al., 2007), isometric squat (Bosco et al., 1999) and multi-way squat exercises 
(Torvinen et al., 2002).

However, due to the fact that a wide range of vibrations, frequencies, amplitudes and time ranges and different vibration application protocols are used, no middle ground has been found so far (Jordan et al., 2005; Krol et al., 2011).

Studies show that vibration is performed acutely in time periods ranging between 5 -s and 30 min and chronically from 10 days to 6 months. These results indicate that there is a need for more studies to determine the optimal vibration intensity and duration of exercise that will have positive effects on performance in relation to the effect of vibration on performance. As a result, the fact that acute vibration studies are common shows that there is absolute need for studied to be conducted on the effects of chronic vibration exercise on the performance of athletes. Just as the effects of long-term vibration application program on balance or athletic performance can be investigated, comparative analysis of different application parameters can be done in the future studies.

\section{References}

Aktuğ, Z. B., Şengür, E., Kızilin, A. M., \& İbiş, S. (2019). Vibrasyon Antrenmanın Dikey Sıçrama ve Çeviklik Performansı Üzerine Akut Etkisi, 2. International Conference on Sports for all and Wellness, 67-75.

Annino, G., Padua, E., Castagna, C., Salvo, V. D., Minichella, S., Tsarpela, O., ... D’Ottavio, S. (2007). Effect of whole body vibration application on lower limb performance in selected high-level balet students, Journal of Strength and Conditioning Research, 21(4), 1072-1076. https://doi.org/10.1519/00124278-200711000-00016

Apple, S., Ehlert, K., Hysinger, P., Nash, C., Voight, M., \& Sells, P. (2010). The Effect of Whole Body Vibration on Ankle Range of Motion and the H-Reflex. North American Journal of Sports Physical Therapy, 5(1), 33-39.

Bedient, A. M., Adams, J. B., Edwards, D. A., Serravite, D. H., Huntsman, H., Mow, S. E., ... Signorile, J. F. (2009). Displacement and frequency for maximazing power output resulting from a bout of whole-body vibration. Journal of Strength and Conditioning Research, 23(6), 1683-1687. https://doi.org/10.1519/JSC.0b013e3181b45bdc

Bogaerts, A., Verschueren, S., Delecluse, C., Claessens, A. L., \& Boonen, S. (2007). Effects of Whole Body Vibration Application on Postural Control in Older Individuals: A 1 Year Randomized Controlled Trial. Gait \& Posture, 26, 309-316. https://doi.org/10.1016/j.gaitpost.2006.09.078

Bosco, C., Colli, R., Introini, E., Cardinale, M., Tsarpela, O., Madella, A., ... Viru, A. (1999). Adaptive Responses of Human Skeletal Muscle to Vibration Exposure. Clinic. Physiol, 19, 183-187. https://doi.org/10.1046/j.1365-2281.1999.00155.x

Cardinale, M., \& Bosco, C. (2003). The use of vibration as an exercise intervention. Exercise and Sport Sciences Reviews, 31(1), 3-7. https://doi.org/10.1097/00003677-200301000-00002

Cardinale, M., \& Wakeling, J. (2005). Whole body vibration exercise: are vibrations good for you? Br J Sports Med, 39, 585-589. https://doi.org/10.1136/bjsm.2005.016857

Cheng, C. F., Cheng, K. H., Lee, Y. M., Huang, H. W., Kuo, Y. H., \& Lee, H. J. (2012). Improvement in running economy after 8 weeks of whole-body vibration application. The Journal of Strength \& Conditioning Research, 26(12), 3349-3357. https://doi.org/10.1519/JSC.0b013e31824e0eb1

Cloak, R., Nevill, A., \& Wyon, M. (2016). The acute effects of vibration application on balance and stability amongst soccer players. European Journal of Sport Science, 16(1), 20-26. https://doi.org/10.1080/17461391.2014.973912

Cochrane, D. J. (2011). The Potential Neural Mechanisms of Acute Indirect Vibration. Journal of Sports Science and Medicine, 10, 19-30.

Cochrane, D. J., \& Hawke, E. J. (2007). Effects of acute upper-body vibration on strength and power variables in climbers. Journal of Strength and Conditioning Research, 21(2), 527-531. https://doi.org/10.1519/00124278-200705000-00041

Cochrane, D. J., Loram, I. D., Stannard, S. R., \& Rittweger, J. (2009). Changes in Joint Angle, Muscle-Tendon Complex Length, Muscle Contractile Tissue Displacement and Modulation of EMG Activity During Acute Whole-Body Vibration. Muscle Nerve, 40(3), 420-429. https://doi.org/10.1002/mus.21330

Cormie, P., Deane, R. S., Triplett, N. T., \& McBride, J. M. (2006). Acute effects of whole-body vibration on muscle activity, strength, and power. Journal of Strength \& Conditioning Research, 20(2), 257-261. 
https://doi.org/10.1519/00124278-200605000-00004

Dallas, G., Krialanis, P., \& Mellos, V. (2014). The acute effect of whole body vibration application on flexibility and explosive strength of young gymnasts. Biol Sport, 31(3), 233-237. https://doi.org/10.5604/20831862.1111852

Despina, T., George, D., George, T., Sotiris, P., George, K., Maria, R., \& Stavros, K. (2014). Short-term effect of whole-body vibration application on balance, flexibility and lower limb explosive strength in elite rhythmic gymnasts. Human Movement Science, 33, 149-158. https://doi.org/10.1016/j.humov.2013.07.023

Epperson, T. A. (2009). The Effect of Whole Body Vibration Platform Application on Hamstring Flexibility. Master of Science, Department of Exercise Sciences Brigham Young University.

Erkmen, N., Suveren, S., Göktepe, A. S., \& Yazıcıoğlu, K. (2007). Farklı branşlardaki sporcuların denge performanslarının karşılaştıılması. Spormetre Beden Eğitimi ve Spor Bilimleri Dergisi, 3, 115-122. https://doi.org/10.1501/Sporm_0000000080

Felicetti, G., Contardi, A., \& Rossato, S. (2004). Proprioceptive evaluation of a group of runners before and after application. The Rehabilitation of Sports Muscle and Tendon Injuries, International Congress.

Filippini, A., Ahmaidi, S., \& Rainoldi, A. (2008). Repeatability of physiologically significant parameters during a stabilometric test on tecnobody prokin platform. Congress of Eufapa, International Congress.

Hagberg, M., Burstro, L., Ekman, A., \& Vilhelmsson, R. (2006). The Association Between Whole Body Vibration Exposure and Musculoskeletal Disorders in The Swedish Work Force is Confounded by Lifting and Posture. Journal of Sound and Vibration, 298, 492-498. https://doi.org/10.1016/j.jsv.2006.06.024

Hansen, M. S., Dieckmann, B., Jensen, K., \& Jakobsen, B. W. (2000). The reliability of balance tests performed on the kinesthetic ability trainer (KAT 2000). Knee Surgery, Sports Traumatology, Arthoscopy, 8(3), 180 185. https://doi.org/10.1007/s001670050211

Hortobágyi, T., Lesinski, M., Fernandez-del-Olmo, M., \& Granacher, U. (2015). Small and inconsistent effects of whole body vibration on athletic performance: a systematic review and meta-analysis. European Journal of Applied Physiology, 115(8), 1605-1625. https://doi.org/10.1007/s00421-015-3194-9

http-1: Uzm. Fzt. Murat Dalkılınç, Fizyoterapi ve Rehabilitasyonda Teknolojik Gelişmeler, http://www.e-Fizyoterapist.Com/E-Kutuphane/Pdf-Belgeler/39-Pdf-Belgeler/86-Fizyoterap-VeRehabltasyo nda-Teknolojk-Gelimeler.Html

http-2: http://www.Eubam.Ege.Edu.Tr/Kandel/Kandel_36.Htm

http-3: http://www.Vibrationapplicationdevice.Com/Galıleo_Fitness.Htm

http-4: http://www.Powerplatestudio.Net/İndex.Php?Option=Com_Content\&Task=View \&İd=17\&Itemid=41

Issurin, V. B., Liebermann, D. G., \& Tennenbaum, G. (1994). Effect of vibratory stimulation application on maximal force and flexibility. J. Sports Sci., 12, 561-566. https://doi.org/10.1080/02640419408732206

Iwamoto, J., Sato, Y., Takeda, T., \& Matsumoto, H. (2012). Whole body vibration exercise improves body balance and walking velocity in postmenopausal osteoporotic women treated with alendronate: Galileo and Alendronate Intervention Trail (GAIT). J. Musculoskelet Neuronal. Interact, 12(3), 136-143.

Jordan, M. J., Norris, S. R., Smith, D. J., \& Herzog, W. (2005). Vibration Application: An Overview of The Area, Application Consequences, and Future Considerations. Journal of Strength and Conditioning Research, 19(2), 459-466. https://doi.org/10.1519/00124278-200505000-00036

Kaçoğlu, C. (2019). Akut Tüm Vücut Vibrasyon Antrenmanının Ünilateral Statik Dengeye Etkilerinin İncelenmesi. Gaziantep Üniversitesi Spor Bilimleri Dergisi, 4(1), 144-156. https://doi.org/10.31680/gaunjss.528141

Kin İşler, A. (2007). Titreşimin Performansa Etkisi. Spor Bilimleri Dergisi. Hacettepe J. of Sport Sciences, 18(1), $42-56$.

Krol, P., Piecha, M., Slomka, K., Sobota, G., Polak, A., \& Juras, G. (2011). The Effect of Whole Body Vibration Frequency and Amplitude on The Myoelectric Activity of Vastus Medialis and Vastus Lateralis. Journal of Sports Science and Medicine, 10, 169-174.

Kurt, C., \& Pekünlü, E. (2015). Acute effect of whole body vibration on isometric strength, squat jump and flexibility in well-trained combat athletes. Biol Sport, 32(2), 115-122. https://doi.org/10.5604/20831862.1134558 
Lam, F. M., Lau, R. W., Chung, R. C., \& Pang, M. Y. (2012). The effect of whole body vibration on balance, mobility and falls in older adults: a systematic review and meta-analysis. Maturitas, 72(3), 206-213. https://doi.org/10.1016/j.maturitas.2012.04.009

Lamont, H. S., Cramer, J. T., Bemden, D. A., Shebab, R. L., Anderson, M. A., \& Bemben, M. G. (2010). The acute effect of whole-body low-frequency vibration on countermovement vertical jump performance in college-aged men. J. Strength Cond. Res., 24(12), 3433-3442. https://doi.org/10.1519/JSC.0b013e3181c1ff7e

Latash, M. L. (1998). Neurophysiological Basis of Movement. Champaign, IL: Human Kinetics.

Liao, L. R., Huang, M., Lam, F. M., \& Pang, M. Y. (2014). Effects of whole-body vibration therapy on body functions and structures, activity, and participation poststroke: a systematic review. Physical Therapy, 94(9), 1232-1251. https://doi.org/10.2522/ptj.20130366

Luo, J., Clarke, M., McNamara, B., \& Moran, K., (2009). Influence of resistance load on neuromuscular response to vibration application. J. Strength Cond. Res., 23(2), 420-426. https://doi.org/10.1519/JSC.0b013e318194241c

Mansfeld, N. J. (2004). Human response to vibration. CRC Press.

Mattacola, C. G., \& Lloyd, J. W. (2012). Effects of a 6-week strength and proprioception application program on measures of dynamic balance: a single case design. Journal of Athletic Application, 32(2), 127-135.

Mester, J., Spitzenpfeil, P., \& Yue, Z. (2005). Vibration loads: potential for strength and power development. In P. V. Komi (Ed.), Strength and Power in Sport (pp. 488-501) Oxford: Blackwell Science. https://doi.org/10.1002/9780470757215.ch24

Mikhael, M., Orr, R., Amsen, F., Greene, D., \& Singh, M. A. (2010). Effect of standing posture during whole body vibration application on muscle morphology and function in older adults: a randomised controlled trial. BMC Geriatr, 15(10), 74. https://doi.org/10.1186/1471-2318-10-74

Mikhael, M., Orr, R., \& Singh, M. A. F. (2010). The Effect of Whole Body Vibration Exposure on Muscle or Bone Morphology and Function in Older Adults: A Systematic Review of the Literature. Maturitas, 66, 150-157. https://doi.org/10.1016/j.maturitas.2010.01.013

Rehn, B., Lidström, J., Skoglund, J., \& Lindström, B. (2007). Effects on leg muscular performance from wholebody vibration exercise: a systematic review. Scand J Med Sci Sports, 17, 2-11. https://doi.org/10.1111/j.1600-0838.2006.00578.x

Rhea, M. R., \& Kenn, J. G. (2009). The effect of acute applications of whole-body vibration on the iTonic platform on subsequent lower-body power output during the back squat. Journal of Strength \& Conditioning Research, 23(1), 58-61. https://doi.org/10.1519/JSC.0b013e3181875045

Ricky, W. L., Lin-Rong, L., Felix, Y., Tilda, T., Raymond, C. C., \& Marco, Y. P. (2011). The Effects of Whole Body Vibration Therapy On Bone Mineral Density And Leg Muscle Strength. Clin Rehabil, 25, 975-988. https://doi.org/10.1177/0269215511405078

Rittweger, J., Schiessl, H., \& Felsenberg, D. (2001). Oxygen-Uptake During Whole Body Vibration Exercise: Comparison with Squatting as a Slow Voluntary Movement. Eur J Appl Physiol, 86, 169. https://doi.org/10.1007/s004210100511

Roelants, M., Verschueren, S. M. P., Delecluse, C., Levin, O., \& Stijnen, V. (2006). Whole-body-vibration-induced increase in leg muscle activity during different squat exercises. Journal of Strength and Conditioning Research, 20(1), 124-129. https://doi.org/10.1519/00124278-200602000-00019

Ronnestad, B. R. (2009). Acute effects of various whole-body vibration frequencies on lower-body power in trained and untrained subjects. Journal of Strength and Conditioning Research, 23(4), 1309-1315. https://doi.org/10.1519/JSC.0b013e318199d720

Schnurrer, T., Vrnanic, L., Ravlic, G. J., Gulan, G., \& Matovinovic, D. (2007). Balance index score a predictive factor for lower sports results or anterior cruciate ligament knee injuries in Croatian female athletes-preliminary study. Coll. Antropol, 31(1), 253-258.

Silva, H. R., Couto, B. P., \& Szmuchrowski, L. A. (2008). Effects of mechanical vibration applied in the opposite direction of muscle shortening on maximal isometric strength. Journal of Strength and Conditioning Research, 22(4), 1031-1036. https://doi.org/10.1519/JSC.0b013e31816a41a1 
Şengür, E., Aktuğ, Z. B., \& Yılmaz, G. (2018). Futbolcularda alt ekstremiteye uygulanan akut vibrasyon antrenmanının şut hızı şut isabeti ve çeviklik performansı üzerine etkisinin incelenmesi. CBÜ Beden Eğitimi ve Spor Bilimleri Dergisi, 14(1), 56-65. https://doi.org/10.33459/cbubesbd.485183

Tillaar, R. V. D. (2006). Will whole-body vibration application help increase the range of motion of the hamstrings? Journal of Strength and Conditioning Research, 20(1), 192-196 https://doi.org/10.1519/00124278-200602000-00031

Tok, İ. (2007). Vibrasyon Antrenmanlarının Spinal Eksitabiliteye Etkileri. Doktora Tezi, Ege Üniversitesi, Sağlık Bilimleri Enstitüsü, Hareket ve Antrenman Bilimleri Anabilim Dalı Programı, İzmir.

Torvinen, S., Kannus, P., Sievänen, H., Järvinen, T. A. H., Pasanen, M., Kontulainen, S., ... Vuori, I. (2002a). Effect of A Vibration Exposure on Muscular Performance and Body Balance. Randomized Cross-Over Study. Clinical Physiology and Functional Imaging, 22(2), 145-152. https://doi.org/10.1046/j.1365-2281.2002.00410.x

Torvinen, S., Sievanen, H., Jarvinen, T. A. H., Pasanen, M., Kontulainen, S., \& Kannus, P. (2002b). Effect of 4-Min Vertical Whole Body Vibration on Muscle Performance and Body Balance: A Randomized Cross-Over Study. Inter Journal Sports Med, 23, 374-379. https://doi.org/10.1055/s-2002-33148

Vrbanic, T. S. L., Ravlic-Gulan, J., Gulan, G., \& Matovinovic, D. (2007). Balance index score as a predictive factor for lower sports results or anterior cruciate ligament knee injuries in Croatian female athletes: Preliminary study. Collegium Antropologicum, 31(1), 253-258.

Wallmann, H. W., Bell, D. L., Evans, B. L., Hyman, A. A., Goss, G. K., \& Paicely, A. M. (2019). the effects of whole body vibration on vertical jump, power, balance, and agility in untrained adults. Int $j$ Sports Phys Ther., 14(1), 55-64. https://doi.org/10.26603/ijspt20190055

Wang, H. H., Chen, W. H., Liu, C., Yang, W. W., Huang, M. Y., \& Shiang, T. Y. (2014). Whole-body vibration combined with extra-load application for enhancing the strength and speed of track and feld athletes. The Journal of Strength \& Conditioning Research, 28(9), 2470-2477. https://doi.org/10.1519/JSC.0000000000000437

Wilcock, I. M., Whatman, C., Harris, N., \& Keogh, J. W. L. (2009). Vibration application: Could it enhance the strength, power, or speed of athletes? Journal of Strength and Conditioning Research, 23(2), 593-603.

Wyon, M., Guinan, D., \& Hawkey, A. (2010). Whole-body vibration application increases vertical jump height in a dance population. Journal of Strength and Conditioning Research, 24(3), 866-870. https://doi.org/10.1519/JSC.0b013e3181c7c640

Yılmaz, A., \& Kin-İşler, A. (2013). Farklı frekanslarda uygulanan akut tüm vücut titreşimin tekrarlı sprint performansina etkisi. Pamukkale Journal of Sport Sciences, 4, 22-32.

\section{Copyrights}

Copyright for this article is retained by the author, with first publication rights granted to the journal.

This is an open-access article distributed under the terms and conditions of the Creative Commons Attribution license (http://creativecommons.org/licenses/by/4.0/). 